\title{
ESSAY
}

\section{The invention of heroes}

\section{The Western public's misapprehension that genius in science is always male and caucasian is partly a legacy of Victorian politics, says Christine MacLeod.}

$\mathrm{n}$ the wake of England's seventeenth-century civil wars, diarist and founder member of the Royal Society John Evelyn praised inventors and scientific discoverers above conquerors.

Such lauding of scientists over leaders was later echoed by many who opposed the costly wars against American colonists and revolutionary France. Indeed in Britain, especially in the eighteenth and nineteenth centuries, it was domestic politics, rather than the desire to promote science or technology per se, that often drove people to bestow heroic status on inventors, engineers and scientists.

Politics influences the public perception of researchers to this day. Yet, in this year of celebration - notably of the works of Charles Darwin, Galileo Galilei and Jean-Baptiste Lamarck - it is salutary to glance back at some early drivers of hero-worship in European science. A brief burst of adulation lavished on 'men of science' in Victorian Britain bolstered public approval of the field and helped improve the country's scientific and technical education. But it has also had a lasting detrimental legacy: it has helped foster the widely held notion that the world's greatest scientists are white, male individualists.

Britain's wave of hero worship began relatively discreetly. Disciples of the eighteenth-century Enlightenment saw in reason a bulwark against tyranny and popery. They expressed admiration of towering intellects, such as Francis Bacon and Isaac Newton, by hanging portraits on their walls and installing monuments in their grounds. After Newton's death in 1727 , three marble statues of him were erected in places of note, including Westminster Abbey in London.

\section{Patents and pedestals}

The real upsurge of politically inspired celebration came in the early nineteenth century. Initially, engineers and inventors, not scientific intellectuals, took centre stage. In 1824 , supported by the Royal Society and leading manufacturers, reform-minded politicians plucked the Scottish inventor and engineer James Watt from posthumous neglect. They began by launching a public subscription for a massive and controversial statue of him, again in Westminster Abbey.

Liberals feared that, in the transition to industrialization, their campaign for parliamentary reform, less taxation and free trade would be frustrated by the wealthy and powerful aristocracy. Lionizing Watt was their attempt to counteract the nation's adulation of Admiral Horatio Nelson and the Duke of Wellington, heroes of Napoleon's defeats at Trafalgar and Waterloo, respectively. The liberal politicians proclaimed Watt to be the war's true hero - his steam engine both history's greatest invention and the foundation of national victory. Moreover, the Industrial Revolution powered by Watt's engine was said to be the real source of the United Kingdom's wealth, international pre-eminence and 'civilizing mission' - an argument that helped clinch the vote for middle-class men in 1832 .

Thirty years later, a concerted campaign by free-traders to abolish the patent system provoked a fresh surge of hero worship. The new Patent Act of 1852 was designed to make patents cheaper and more accessible. But during the next 20 years, a faction of economic liberals and engineers, including Isambard Kingdom Brunel, joined a Europe-wide clamour

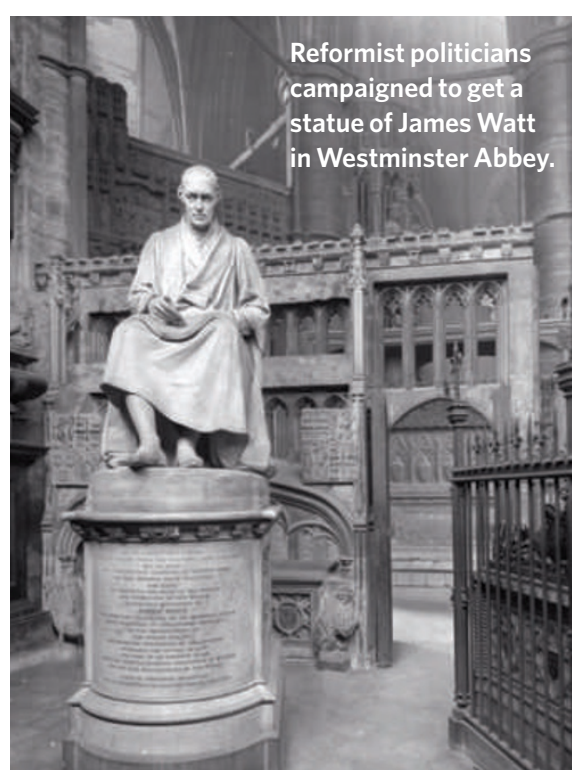

trialization. Machine-makers, railwaymen and spinning-machine operators cherished the memory of Watt and others who had succeeded through ingenuity and enterprise. They commemorated them on trade union insignia, ritually toasted their memory and donated generously to their memorials. In Bolton, workers raised a statue to the spinning-machine inventor Samuel Crompton, reminding the 'cotton lords' that a poor man's genius had created their wealth; in Penzance, they strove to ensure that Humphry Davy's invention of the miners' safety lamp and its contribution to coalowners' profits would never be forgotten.

All this commemoration of lowly men turned successful inventors helped win people's respect for the upper echelons of the working class. Just as the campaign to glorify Watt aided the enfranchisement of middle-class men, so this new wave of commemoration helped convince Parliament to extend the right to vote to skilled male workers in 1867.

Newton apart, Victorian society was slow against patents, which they believed were harmful to the economy, unfair and unnecessary. Bennet Woodcroft, a leading figure in patent reform, was tireless in the patent system's defence, collecting portraits and memoirs of inventors, salvaging iconic inventions and launching the Patent Museum (a forerunner of London's Science Museum). Woodcroft even dug up the second Marquess of Worcester in a fruitless attempt to find the model steam engine the seventeenth-century inventor had requested be buried with him.

Proponents of the patent system evidently had all the best tunes. Without a patent, an inventor (typically a working man) was at the mercy of grasping capitalists; with one, he could aspire to fame and fortune. It was a story that chimed with the beliefs of many in the skilled trades that rose on the tide of indus- to extend the accolades it had showered on inventors and engineers to more academically minded scientists; ideas and understanding took a back seat to innovation. It was William Thomson's role in laying the first transatlantic telegraph cable, for example, not his research in electricity and thermodynamics, that brought him celebrity. His many honours included, in 1892, elevation to the House of Lords as Baron Kelvin - a first for a scientist.

\section{A turning tide}

Yet wherever possible, scientists took advantage of the nation's appetite for heroes. For instance, after Darwin's death in 1882, leading scientists overturned his wish to rest in his local churchyard, recognizing the propaganda value of a Westminster Abbey funeral.

By 1900, the tide of public enthusiasm for 


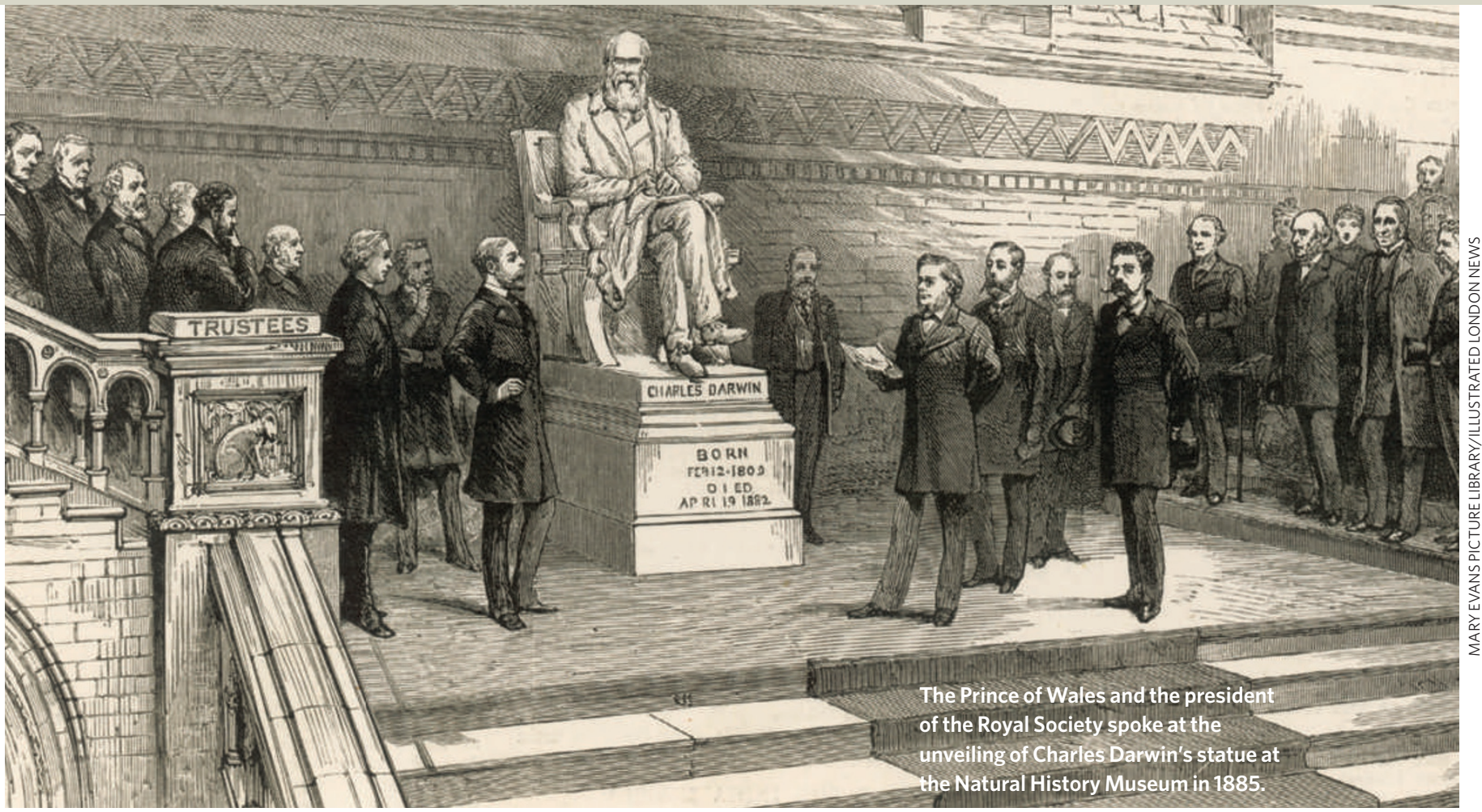

both inventors and scientists was turning. Tales of self-help seemed hackneyed, social surveys demonstrated that industrialization had not eradicated poverty and the heroic rhetoric of invention had served its purpose. Half of all working men could now vote, and the patent system had been secured.

Few inventors could match the showmanship of the United States' Thomas Edison, with his dazzling displays of electric light, or of Italy's Guglielmo Marconi, best known for developing wireless telegraphy. Nor could they outdo the bravura of the American Wright brothers in managing to build as well as pilot the world's first successful aeroplane. Meanwhile, imperial exploration and conquest offered more exotic heroes whose widely reported adventures made most British inventors seem lacklustre.

When inventors started to lose popularity, academic scientists tried to present themselves as having a more important role. They started to depict invention either as the automatic spin-off from scientific research or as destined to fail if the inventor lacked a scientific education. Their increasing use of the term 'applied science' neatly expunged the role of the inventor.

An emerging rhetoric of 'pure science' insisted that researchers be funded to pursue their intellectual goals with no concern for utility, but that utility would ultimately reward society's trust. Purveyors of this view fastened, in particular, on Michael Faraday. In 1891, The Times newspaper reported how leading physicists celebrating the centenary of his birth had said: "All of us are now enjoying the material results of Faraday's research ... but his eye was fixed upon truth itself, and not upon the useful results that might come from the knowledge of it."

Such views boosted the status of science and scientists above that of inventors and engineers, but they didn't produce a new crop of scientific heroes. After 1914, science, technology and engineering became more anonymous. In corporate research and development labs, discoveries and inventions were claimed by faceless teams and obscured by brand names; in university departments, scientific publications took precedence over patents. The enormous losses of the Great War monopolized public commemorations. Historians played down the role of 'great men', the press grew more cynical, and culture as a whole less deferential.

\section{Death of the science celebrity}

Numerous researchers have caught the UK public eye in recent years: Alexander Fleming, James Watson, Francis Crick, Tim Berners-Lee and Stephen Hawking, to name a few. But footballers, musicians and film stars, not scientists,
"Machine-makers, railwaymen and spinning-machine operators cherished the memory of Watt." inventors or engineers, now receive the kind of nationwide celebrity status and commemorative fervour once lavished on Newton, Watt, Brunel and Darwin.

The United Kingdom's enthusiasm for scientific heroes may have been short-lived, but the reputations of those celebrated by the Victorians continue to influence people's perception of genius in science. Among the public and media, they reinforce the notion that the country's glory days of science and invention are long gone, and that its engineering has never recovered from the deaths in 1859 of Brunel and Robert Stephenson. Globally, their reputations feed a stereotype of great scientists as male and caucasian.
A poll conducted in 2005 to determine who the French public viewed as their country's greatest people in history put Marie Curie fourth - yet she was the only woman in the six scientists and inventors included in the top 100. All 19 scientists and inventors who made it onto the list in an equivalent poll for the United Kingdom were male; as were the nine on a similar list compiled in the United States. Internationally, Europeans such as Darwin, Newton, Albert Einstein and Galileo enjoy iconic status on a scale that far surpasses the acclaim surrounding any non-Western scientist. More than 100 countries have issued Newton and Einstein stamps in recent years, for instance, whereas non-Western scientists rarely appear on stamps outside their own country.

It's unreasonable to heap serious blame on the white, whiskered Victorians - immortalized in stone and marble - for well-known gender and ethnic biases in recruitment. After all, Darwin has hardly deterred women from pursuing biology. But the culture of commemoration, initiated largely in Victorian Britain, carries the subliminal message that genius is male and caucasian. Indeed, it enshrines the very notion of scientific 'genius' and ties it firmly to the past.

Christine MacLeod is in the School of Humanities, University of Bristol, 11 Woodland Road, Bristol, BS8 1TB, UK, and is the author of Heroes of Invention: Technology, Liberalism and British Identity, 1750-1914 (Cambridge, 2007). e-mail:C.Macleod@bristol.ac.uk

\section{FURTHER READING}

Browne, J. Br. J. Hist. Sci. 38, 251-274 (2005).

Fara, P. Newton: the Making of Genius (Picador, 2002). Jordanova, L. Defining Features: Scientific and Medical Portraits, 1660-2000 (Reaktion, 2000).

Oldenziel, R. Making Technology Masculine: Men, Women and Modern Machines in America, 1870-1945 (Amsterdam Univ. Press, 1999). 